\title{
Integrating Landsat TM/ETM+ and Numerical Modeling to Estimate Water Temperature in the Tigris River under Future Climate and Management Scenarios
}

\author{
Muhanned D. Al-Murib ${ }^{1, *}$,, Scott A. Wells ${ }^{1,2}$ and Stefan A. Talke ${ }^{1}$ \\ 1 Department of Civil and Environmental Engineering, Portland State University, Portland, OR 97207-0751, \\ USA; wellss@pdx.edu (S.A.W.); talke@pdx.edu (S.A.T.) \\ 2 Collaborative Center for Geo-hazards and Eco-Environment in Three Gorges Area, Three Gorges University, \\ Yichang 443000, China \\ * Correspondence: almuribmuhanned@gmail.com
}

Received: 11 February 2019; Accepted: 24 April 2019; Published: 28 April 2019

\begin{abstract}
Modeling the water quality of rivers and assessing the effects of changing conditions is often hindered by a lack of in situ measurements for calibration. Here, we use a combination of satellite measurements, statistical models, and numerical modeling with CE-QUAL-W2 to overcome in situ data limitations and evaluate the effect of changing hydrologic and climate conditions on water temperature $\left(T_{w}\right)$ in the Tigris River, one of the largest rivers in the Middle East. Because few in situ estimates of $T_{w}$ were available, remotely-sensed estimates of $T_{w}$ were obtained from Landsat satellite images at roughly 2 week intervals for the year 2009 at the upstream model boundary (Mosul Dam) and two locations further downstream, Baeji and Baghdad. A regression was then developed between air temperature and Landsat $T_{w}$ in order to estimate daily $T_{w}$. These daily $T_{w}$ were then used for the upstream model boundary condition and for model calibration downstream. Modeled $T_{w}$ at downstream locations agreed well with Landsat-based statistical estimates with an absolute mean error of $<1{ }^{\circ} \mathrm{C}$. A model sensitivity analysis suggested that altering upstream river discharge had little impact on downstream $\mathrm{T}_{\mathrm{w}}$. By contrast, a climate change scenario in which air temperatures were increased by $2{ }^{\circ} \mathrm{C}$ resulted in a $0.9{ }^{\circ} \mathrm{C}$ and $1.5^{\circ} \mathrm{C}$ increase in $T_{w}$ at Baeji and Baghdad, respectively. Since $T_{w}$ is a fundamental state variable in water quality models, our approach can be used to improve water quality models when in situ data are scarce.
\end{abstract}

Keywords: Tigris River; water temperature modeling; remote sensing; CE-QUAL-W2; climate change

\section{Introduction}

The Tigris River is one of the largest rivers in the Middle East and is one of two primary rivers, along with the Euphrates River, that provide the primary source for drinking and irrigation water in Iraq. Water quality in the Tigris River affects major cities along the river such as Mosul, Baeji, Tikrit, Samarra, Baghdad, Kut, and Misan. Pollution discharges in the Tigris River can also affect water quality in the Euphrates River since both rivers are connected through Tharthar Lake, an artificial lake located $100 \mathrm{~km}$ northwest of Baghdad [1].

A primary indicator of water quality is water temperature $T_{w}$, since it influences chemical and biochemical processes in waterbodies [2,3]. Water temperature also directly impacts the flora and fauna of aquatic ecosystems, and eutrophication processes [4], plays an essential role in altering bio-geochemical processes of a waterbody [5], and affects timing of fish lifecycle events (e.g., spawning) [6]. Changes in water temperature can be driven by climate variations [7], and changes 
in thermal pollution from industrial processes [8] and land use [9]. Changes in a stream's water temperature were found to be strongly associated with changes in air temperature as a result of climate change, and to a lesser extent by changes in the stream's flow rate [10].

In a developing country such as Iraq, conventional monitoring of water quality (including $\left.T_{w}\right)$ is challenging due to economic and logistical challenges. We therefore investigate whether a combination of satellite remote sensing data and numerical modeling can fill this knowledge gap. Remote sensed images have been used to monitor water temperature, turbidity, and chlorophyll-a in waterbodies $[5,11,12]$ and are well-suited to define climatological averages, assess spatial patterns due to river flow and other forcing factors [13], and study long-term changes in natural resources [14]. Remote sensed images therefore provide an attractive way to assess water temperature, in particular because of their spatial coverage and ability to fill gaps in the in situ record [15]. To estimate seasonal changes in $T_{w}$ at the river length scale, we use the Landsat 5 thematic mapper (TM) and Landsat 7 enhanced thematic mapper plus (ETM+), due to its roughly 2 week return period and spatial resolution of 60-120 m. Since the width in the Tigris River varies between 150-300 m, the spatial resolution of satellite pixels is adequate for estimating $T_{w}$. Brightness temperature $(B T)$ is extracted from the spectral radiance in the thermal bands of Landsat TM/ETM+. An emissivity correction is required to obtain the radiant temperature in waterbodies and may vary with sediment concentration, algae concentration, or other water properties [16].

Many studies have validated the use of Landsat data and, more generally, long-wave infrared radiation to estimate surface water temperature and have explained the advantages and potential drawbacks of this approach [17-24]. A typical maximum uncertainty of $0.5{ }^{\circ} \mathrm{C}$ was estimated for different water body types [16]. Within a river, the action of bottom-derived turbulence produces boils that break the surface and introduce spatial variations in water temperature as much as $0.5-1{ }^{\circ} \mathrm{C}$ during periods of strong surface heating or cooling (e.g., [25]). Averaged over a large region of boils (as a Landsat image does), the actual bias or difference between the average surface temperature and in situ temperature is much smaller and is on the order of $0.1-0.2{ }^{\circ} \mathrm{C}$ [25]. Recording only the surface of the water body is one limitation of using remote sensing [22]; spatial resolution, spectral resolution, radiometric resolution, and temporal resolution are other limitations of using satellite images. Further limitations and sources of error in a river can include contamination by surface effects, clouds, and shadows from clouds, buildings, and other objects [16]. Nonetheless, these errors and biases are small compared to water temperature changes over the seasonal time-scale considered here, provided that careful data validation and quality assurance techniques are applied to remove spurious data.

Landsat images are easily available and provide spatially and temporally continuous earth observations. Landsat TM/ETM+ images might effectively be used to link spatial and temporal influences on surface water temperature with in situ observations [17]. Coarse spatial resolution imagery from moderate resolution imaging spectroradiometer (MODIS) have been widely used to assess spatial and temporal temperature variation in large lakes and reservoirs [26], while medium spatial resolution satellite imagery from Landsat have been used to map and quantify the longitudinal and temporal thermal patterns along rivers [27]. Therefore, Landsat thermal images can accurately be used to estimate water temperature in river systems due to providing finer spatial resolution compared with MODIS. Compared with airborne remote sensed images, which are always limited to small areas in most cases, thermal images acquired from Landsat sensors provide a long time period global coverage [21].

In this paper, we investigate the feasibility and utility of: (1) using satellite remote sensing to estimate seasonal patterns of $T_{w}$ in the Tigris River; (2) using satellite estimates of $T_{w}$ and in situ meteorological data to estimate daily and synoptic-scale variations in $T_{w}$ (e.g., reaction to heat waves); (3) integrating remote sensing with numerical modeling, and (4) using numerical modeling to study the impacts on $T_{w}$ of changing upstream hydrological conditions and future climate change. 


\section{The Tigris River Study Area}

Along with the Euphrates River, the $1850 \mathrm{~km}$ long Tigris River forms the primary freshwater system in Iraq. About $58 \%$ of the Tigris basin lies within Iraq with a catchment area of $253,000 \mathrm{~km}^{2}$. The average annual flow of the Tigris River is $672 \mathrm{~m}^{3} / \mathrm{s}$ as it enters Iraq with a mean average of 701 $\mathrm{m}^{3} / \mathrm{s}$ between 1960-1984 dropping to $596 \mathrm{~m}^{3} / \mathrm{s}$ between 1985-2008 [28]. Generally, peak flows in the Tigris River occur between April and May. Our study area extends from Mosul Dam (River Km, Rkm, 0 ) to Kut Barrage (Rkm 880) as shown in Figure 1. Four tributaries join the Tigris River study area: The Upper Zab (Rkm 120), the Lower Zab (Rkm 240), Adhaim River (Rkm 458), and Diyala River (Rkm 605). Water from the Tigris River at Samarra Barrage located $125 \mathrm{~km}$ upstream of Baghdad is diverted to Tharthar Lake, an artificial lake located $100 \mathrm{~km}$ northwest of Baghdad through the Tigris-Tharthar canal, $75 \mathrm{~km}$ in length. This water transfer was originally conceived to prevent flooding in Baghdad. High saline water is diverted from Tharthar Lake to the Tigris River during dry seasons through the $65 \mathrm{~km}$ long Tharthar-Tigris canal. This canal enters the Tigris River $25 \mathrm{~km}$ upstream of Baghdad.

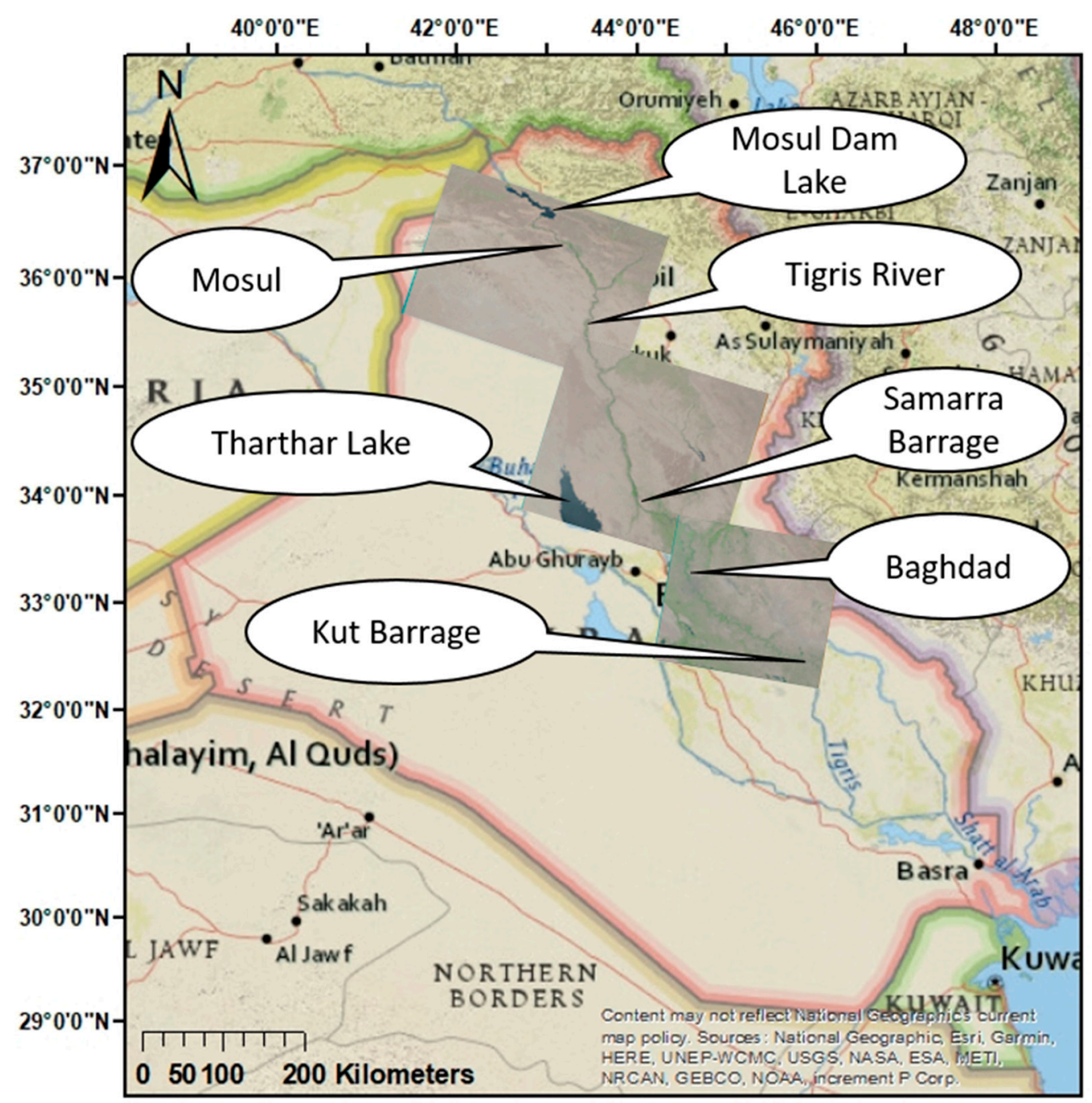

Figure 1. The Tigris River study area from Mosul Dam (River km 0) to Kut Barrage (River km 880).

\section{Methodology}

The thermal band of the Landsat 5 thematic mapper (TM) and Landsat 7 enhanced thematic mapper plus (ETM+) sensors were used to estimate $T_{w}$ throughout the study domain. We focus on the year 2009 since both daily flow and meteorological data were available for this year, though selected images were obtained from the year 2004 to validate our approach using sparse in situ $T_{w}$. 
Satellite-based estimates of $T_{w}$ were then used in conjunction with daily air temperature measurements to develop a statistical model of $T_{w}$. The statistical model then formed the model boundary condition for $T_{w}$ at Mosul Dam and enabled model verification at selected downstream locations.

\subsection{Satellite Data Acquisition}

Publically available Landsat archives were accessed from the US Geological Survey (USGS) database at http://glovis.usgs.gov/. Three Landsat images were stitched together to cover the Tigris River study area (Figure 1) including path/row 170/35, 169/36, and 168/37; as a result, images were typically made on different days and a synoptic view of the entire study region was rarely available. We used thermal bands (band 6) level 1 and level 2 of both Landsat 5 TM and Landsat 7 ETM+ for the simulated year of 2009; level 2 data were used to define clouds, land pixels, and data quality, while level 1 data were used for actual $T_{w}$ estimates. Generally, Landsat images were acquired at 10:30 AM local time in Iraq with $(7000 \times 8000)$ pixels each with a spatial resolution of $120 \times 120 \mathrm{~m}$ and $60 \times 60 \mathrm{~m}$ for thermal bands of Landsat 5TM and Landsat 7 ETM+ respectively.

\subsection{Estimation of Surface Water Temperature of the Tigris River}

To estimate $T_{w}$, the digital number associated with each Landsat pixel was converted into radiance and then into the brightness temperature (BT) using the inverse of Planck's law [29-31]. An emissivity correction was applied to estimate the radiant temperature of the Tigris River. An emissivity of 0.975 was applied and was assumed constant throughout the year. Thirty-six Landsat images were available to estimate $T_{w}$ at Mosul Dam (upstream model boundary), while 20 and 26 Landsat images were available to estimate $T_{w}$ at Baeji and Baghdad, respectively. Table 1, Table 2, and Table 3 list Landsat images used in this study to estimate $T_{w}$ at Mosul Dam, Baeji, and Baghdad, respectively. Level 2 data were used to remove land-pixels and pixels contaminated by clouds. To reduce the noise in the remaining pixels, a boxed region of $2 \times 2 \mathrm{~km}$ was defined at Mosul Dam, Baeji, and Baghdad (see Figure 2), and the median value of water temperature within the box region was used to estimate $T_{w}$ (see e.g., [29]). We validated this approach using in situ estimates of $T_{w}$ (10 sampling points) (see chapter three in [32]) at a station located $3 \mathrm{~km}$ upstream of the confluence of the Tigris River with the Tharthar-Tigris canal for the period from June through December of 2004. The comparison showed a significant correlation between satellite-based $T_{w}$ and field data, with an $\mathrm{R}^{2}$ value of 0.92 and a $p$-value of $4 \times 10^{-6}$. The same method was used to estimate $T_{w}$ at Baeji and Baghdad using a combination of Landsat 5 TM and Landsat 7ETM+. Figure 3 shows snapshots of $T_{w}$ at both Baeji and Baghdad during different times of the year. Seasonal variability of $\sim 20^{\circ} \mathrm{C}$ is observed at both locations between winter and summer. Water is generally slightly warmer in Baghdad, though the lack of field data precludes direct analysis. Some spatial variability and error are evident in each image, caused for example by bridges in Baghdad, contamination from land pixels, or cloud effects not captured by Level 2 data. We choose a measurement location away from obvious sources of bias and our median filter reduced the effects of outliers; however, some bias in each measurement remained possible. Nevertheless, as shown below, the good correlation of Landsat $T_{w}$ with meteorological measurements (Section 3.3) and sparse in situ data validated our approach and suggested that errors were primarily random and not systematic. Moreover, the good comparison between Landsat $T_{w}$ and our process-based numerical model (see results) also suggested that the satellite images were correctly capturing both seasonal and shorter-time scale fluctuations. 
Table 1. Landsat images used to estimate $T_{w}$ in the Tigris River at Mosul.

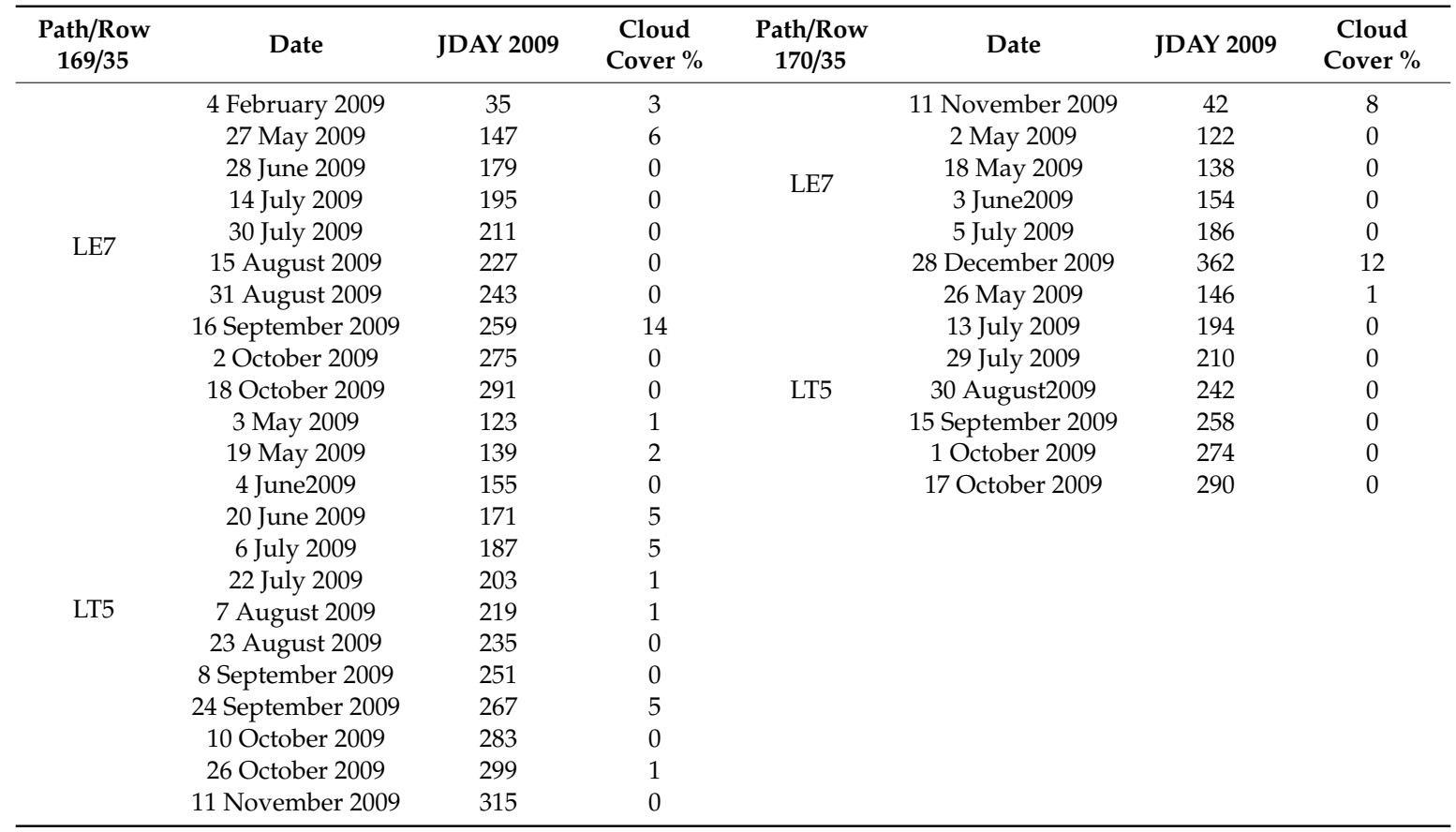

Table 2. Landsat images used to estimate $T_{w}$ in the Tigris River at Baeji.

\begin{tabular}{|c|c|c|c|c|c|c|c|}
\hline $\begin{array}{c}\text { Path/Row } \\
\text { 169/36 }\end{array}$ & Date & JDAY 2009 & $\begin{array}{c}\text { Cloud } \\
\text { Cover \% }\end{array}$ & $\begin{array}{c}\text { Path/Row } \\
\text { 169/36 }\end{array}$ & Date & JDAY 2009 & $\begin{array}{c}\text { Cloud } \\
\text { Cover } \%\end{array}$ \\
\hline \multirow{9}{*}{ LE7 } & 4 February 2009 & 35 & 3 & \multirow{9}{*}{ LT5 } & 3 May 2009 & 123 & 16 \\
\hline & 27 May 2009 & 147 & 0 & & 4 June 2009 & 155 & 0 \\
\hline & 30 July 2009 & 211 & 2 & & 20 June 2009 & 171 & 0 \\
\hline & 15 August 2009 & 227 & 0 & & 22 July 2009 & 203 & 3 \\
\hline & \multirow[t]{5}{*}{18 October 2009} & 291 & 0 & & 8 September 2009 & 251 & 0 \\
\hline & & & & & 24 September 2009 & 267 & 0 \\
\hline & & & & & 10 October 2009 & 283 & 2 \\
\hline & & & & & 26 October 2009 & 299 & 3 \\
\hline & & & & & 11 November 2009 & 315 & 0 \\
\hline
\end{tabular}

Table 3. Landsat images used to estimate $T_{w}$ in the Tigris River at Baghdad.

\begin{tabular}{|c|c|c|c|c|c|c|c|}
\hline $\begin{array}{c}\text { Path/Row } \\
\text { 168/37 }\end{array}$ & Date & JDAY 2009 & $\begin{array}{c}\text { Cloud } \\
\text { Cover } \%\end{array}$ & $\begin{array}{c}\text { Path/Row } \\
\text { 169/37 }\end{array}$ & Date & JDAY 2009 & $\begin{array}{c}\text { Cloud } \\
\text { Cover } \%\end{array}$ \\
\hline \multirow{9}{*}{ LE7 } & 12 January 2009 & 12 & 14 & \multirow{9}{*}{ LE7 } & 19 January 2009 & 19 & 14 \\
\hline & 13 February 2009 & 44 & 7 & & 20 February 2009 & 51 & 9 \\
\hline & 17 March 2009 & 76 & 0 & & 8 March 2009 & 67 & 11 \\
\hline & 18 April 2009 & 108 & 1 & & 27 May 2009 & 147 & 8 \\
\hline & 21 June 2009 & 172 & 0 & & 15 August 2009 & 227 & 0 \\
\hline & 7 July 2009 & 188 & 0 & & 16 September 2009 & 259 & 3 \\
\hline & 23 July 2009 & 204 & 0 & & 2 October 2009 & 275 & 0 \\
\hline & 25 September 2009 & 268 & 0 & & 18 October 2009 & 291 & 1 \\
\hline & 11 October 2009 & 284 & 2 & & & & \\
\hline
\end{tabular}



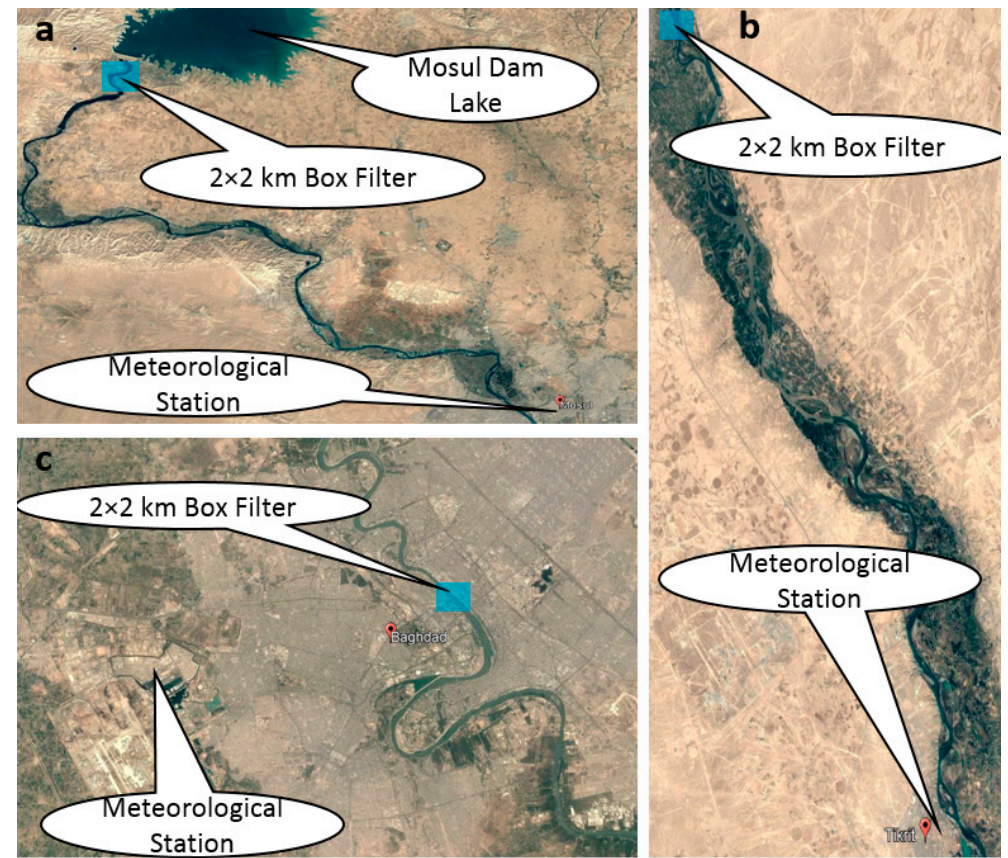

Figure 2. Meteorological stations and box filter regions at (a) Mosul; (b) Baeji; and (c) Baghdad.

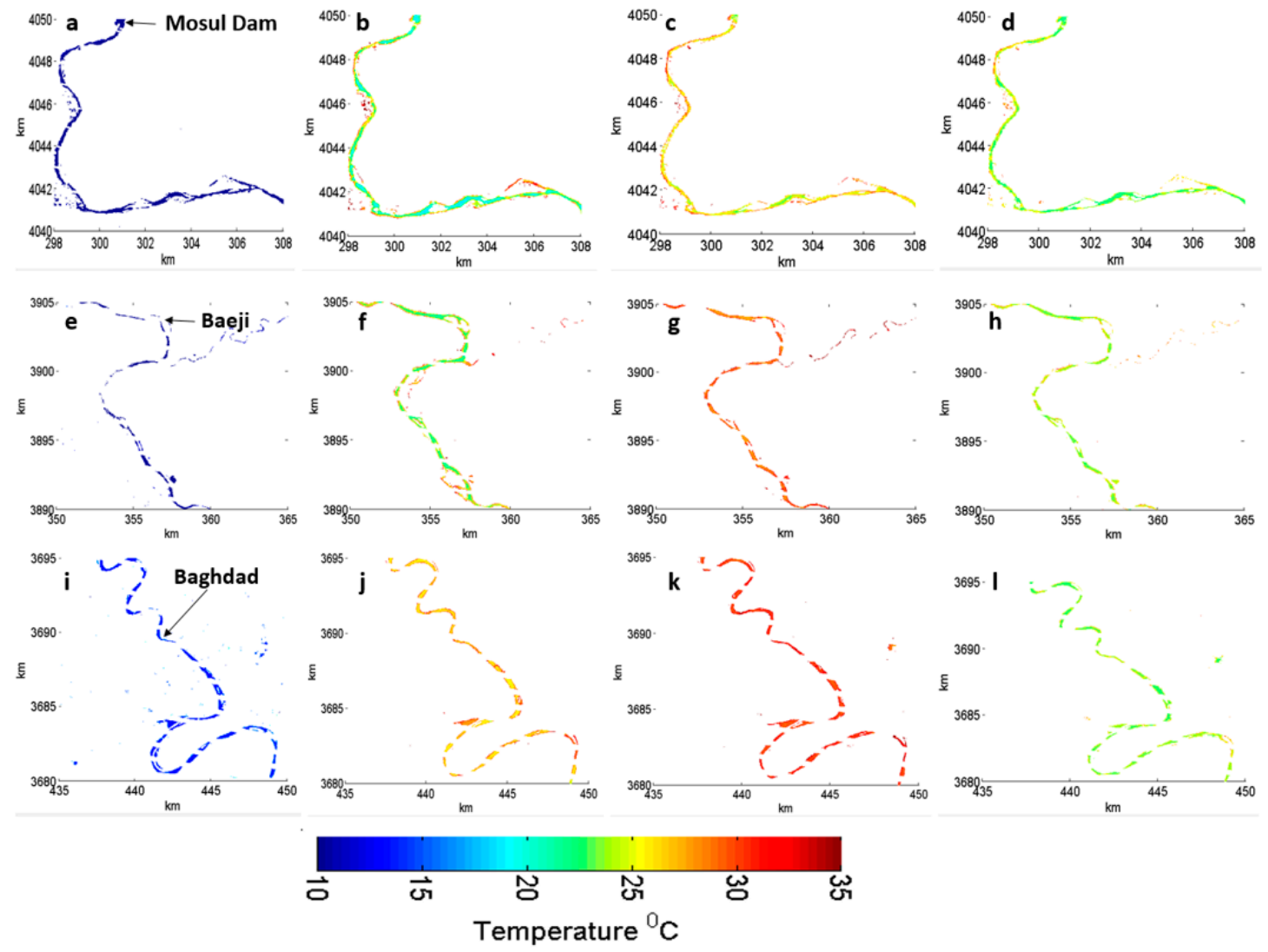

Figure 3. Seasonal variation in $T_{w}$ in 2009, estimated from Landsat satellite images for Mosul Dam on (a) 10 January; (b) 26 May; (c) 30 August; (d) 1 October for Baeji on (e) 4 February ; (f) 27 May; (g) 15 August; (h) 2 October and for Baghdad on (i) 4 February; (j) 27 May; (k) 15 August; (1) 2 October.

\subsection{Statistical Algorithms of $T_{w}$}

To model the water temperature of the Tigris River, both an upstream boundary condition and in-stream values for model verification were needed. Because Landsat-based $T_{w}$ estimates were 
under-sampled in time, we developed a statistical model to obtain an estimate of $T_{w}$ at Mosul Dam, Baeji, and Baghdad at the daily time scale. As shown below, this approach captured daily and synoptic scale (weather-pattern based) variations and was therefore more appropriate than one based on linear interpolation from sparse remote sensing data. Moreover, the statistical model formed a basis for validating our numerical model within the domain, particularly since fewer satellite-based estimates were available downstream of Mosul.

To develop a statistical model for $T_{w}$, we correlated satellite-based $T_{w}$ with corresponding weighted air temperatures $\left(T_{a}\right)$ at Mosul, Baeji, and Baghdad. Since $T_{a}$ includes meteorological variability, daily average values of $T_{a}$ were weighted using an exponential filter, as described in [33]:

$$
T_{a}=\frac{\sum_{n=1}^{t / \Delta t} T_{a}(t-n \Delta t) \exp [-(n-1) k \Delta t]}{\sum_{n=1}^{t / \Delta t} \exp [-(n-1) k \Delta t]}
$$

where $t$ is the response time in the water column ( 5 days), $\Delta t$ is the time step ( 1 day), and $k$ (measured in $\left.\mathrm{s}^{-1}\right)$ is the surface heat exchange coefficient $\left(\mathrm{J} / \mathrm{s} \mathrm{m}^{2}{ }^{\circ} \mathrm{C}\right.$ ) divided by (water density $\times$ Specific heat $\times$ average depth in the water) $\left(\mathrm{s}\left(\mathrm{J} / \mathrm{m}^{2}{ }^{\circ} \mathrm{C}\right)\right)$.

The exponential filter reduced the weight of air temperature as the time lag increased; essentially, meteorological conditions with a lag of 1-day influenced water temperature more than air temperature several days earlier. We experimented with various time-lags and found that a 5-day lag minimized error.

A continuous water temperature model with air temperature lags of up to 5 days performed best, resulting in a $1.15^{\circ} \mathrm{C}$ standard error with statistically-based estimates of $T_{w}$. These air temperature measurements were provided by the Iraqi Ministry of Transportation. The basic regression equation follows [34] and is:

$$
T_{w}=a+b T_{a}+c Q
$$

where $T_{w}$ is water temperature $\left({ }^{\circ} \mathrm{C}\right), T_{a}$ is 5 days weighted average of air temperature $\left({ }^{\circ} \mathrm{C}\right), Q$ is flowrate $\left(\mathrm{m}^{3} / \mathrm{s}\right)$, and $a, b, c$ are coefficients.

Although flowrate $Q$ theoretically affects $T_{w}$ by altering the mean depth and advection rate, we found no statistically significant relationship (we revisited this later with a sensitivity analysis of the model). Therefore, flowrate was eliminated from the $T_{w}$ regression equations such that:

$$
\begin{gathered}
T_{w(\text { Mosul })}=4.30+0.73 \times T_{a}, \\
T_{w(\text { Baeji })}=4.77+0.70 \times T_{a}, \\
T_{w(\text { Baghdad })}=3.42+0.76 \times T_{a},
\end{gathered}
$$

The statistical relationship at Mosul Dam $\left(R^{2} 0.846, p\right.$-value $\left.9.4 \mathrm{E} \times 10^{-17}\right)$ was used for the model's upstream boundary conditions. The relationships at Baeji $\left(R^{2} 0.878, p\right.$-value $\left.3.33 \times 10^{-11}\right)$ and Baghdad $\left(R^{2} 0.968, p\right.$-value $\left.8.40 \times 10^{-21}\right)$ were used for comparison with model predictions. The c coefficients and $p$-values were -0.0002 and $0.93,-0.0004$ and 0.74 , and 0.008 and 0.28 , at Mosul Dam, Baeji, and Baghdad, respectively.

Figure 4 shows scatter plots of $T_{w}$ estimated from Landsat images and the 5-day weighted average of air temperature (Ta) at Mosul Dam, Baeji, and Baghdad.

A 95\% confidence interval (CI) was estimated for remotely sensed water temperatures at both Baeji and Baghdad using:

$$
95 \% C I=T_{w} \pm t_{n-2} * S_{y} \sqrt{\frac{1}{n}+\frac{\left(T_{a}-\bar{x}\right)^{2}}{(n-1) S^{2}}},
$$

where $T_{w}$ is water temperature estimated from statistical models, $T_{a}$ is 5 days weighed air temperature, $S_{\mathrm{y}}$ is the standard error of the developed statistical model, $S$ is the variance in $T_{a}$ (square of standard deviation), $\mathrm{n}$ is sample size, $\bar{x}$ is the average of $T_{a}$ in the sample. 

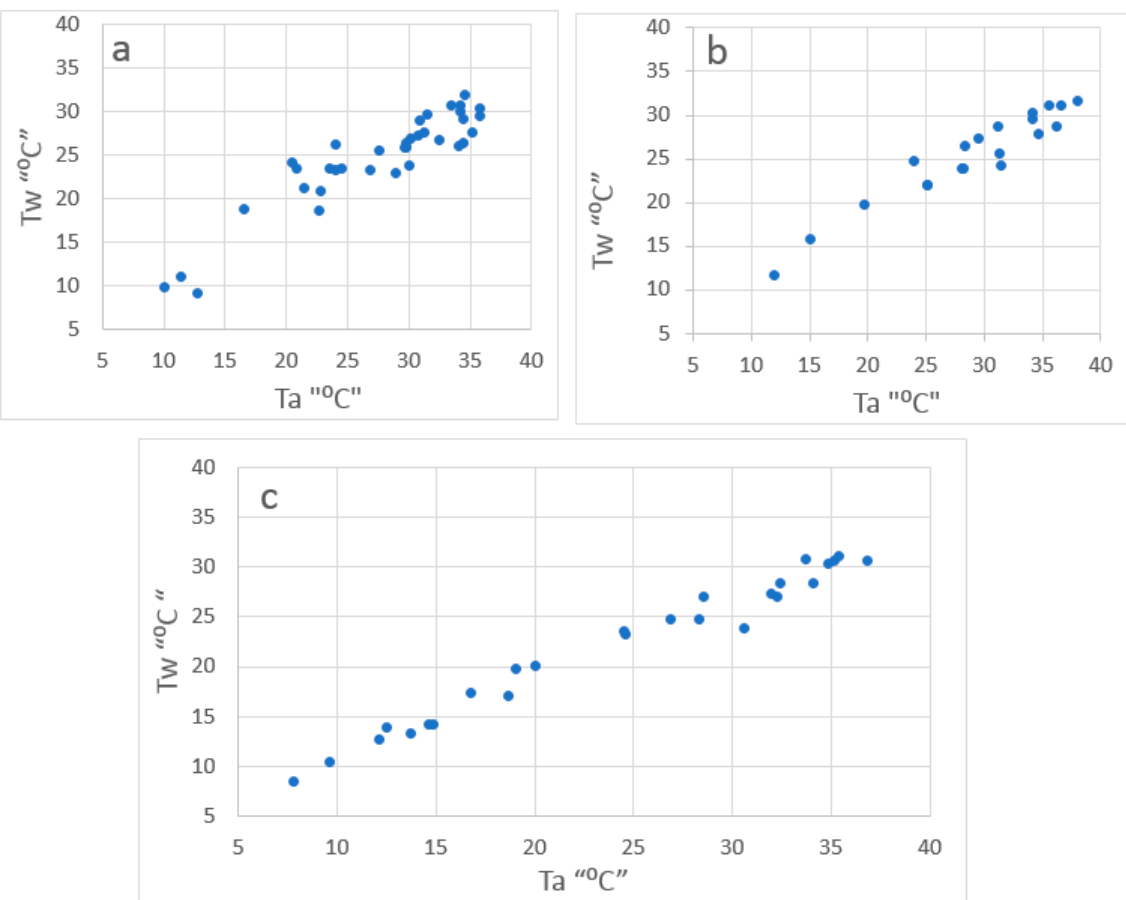

Figure 4. Satellite $T_{w}$ and 5 days weighted average of air temperature $T_{a}$ at Mosul Dam (sample size 36), Beaji (sample size 20), and Baghdad (sample size 26). (a) Mosul, (b) Baeji, and(c) Baghdad.

Estimated daily $T_{w}$ at Mosul Dam, Baeji, and Baghdad used in the Tigris River model are shown in Figure 5. Estimates of $T_{w}$ showed that water temperatures of the Tigris River ranged between $6{ }^{\circ} \mathrm{C}$ and $31^{\circ} \mathrm{C}$ over the year 2009, with the largest temporal gradients observed in spring/fall and the smallest gradients observed during the summer. While factors such as image cloud cover and contamination of river pixels by land reflection could possibly cause some uncertainty in the measurements, the general pattern follows expected seasonal patterns.
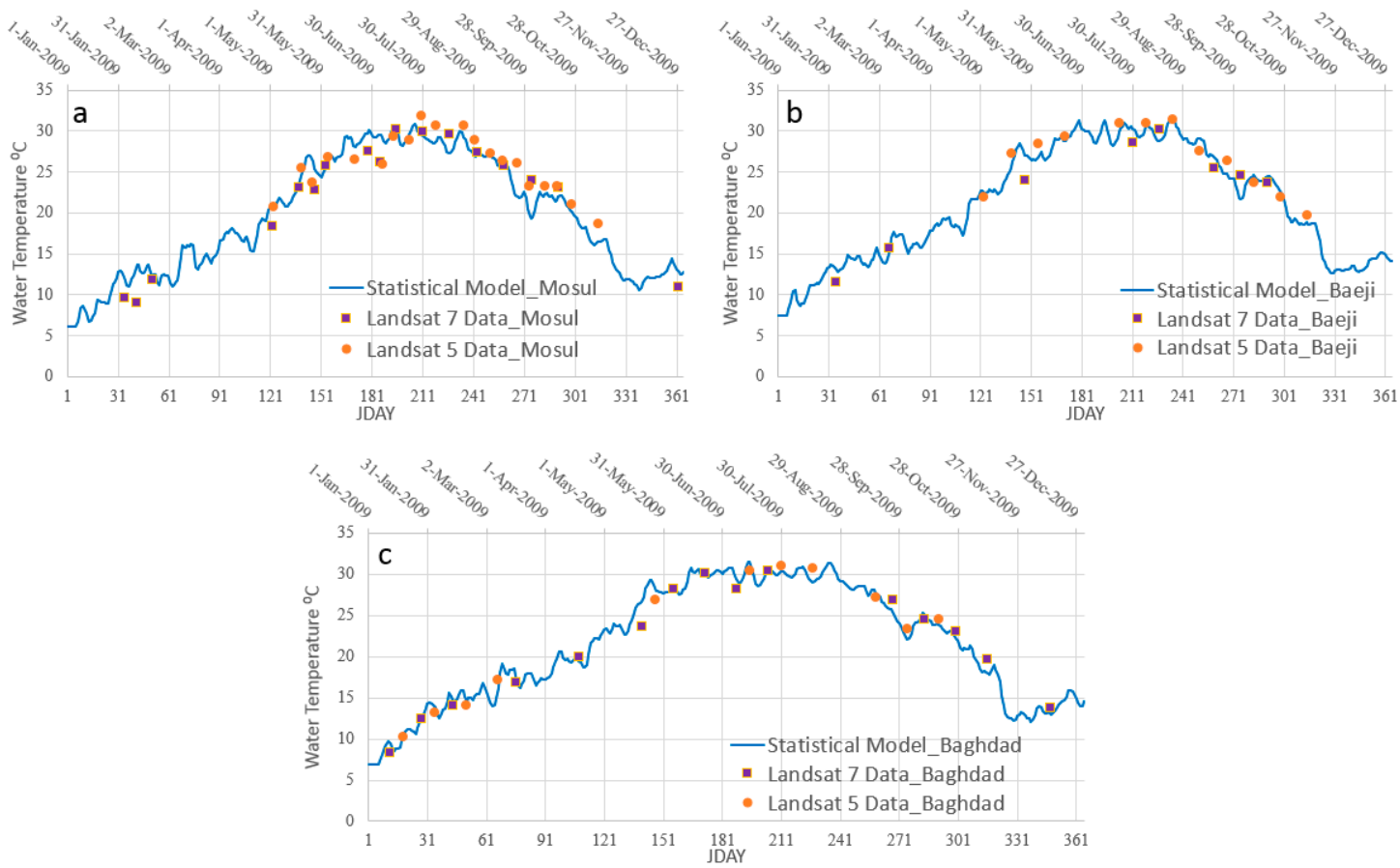

Figure 5. Satellite derived $T_{w}$ and daily $T_{w}$ estimated from $T_{w}$ statistical models at (a) Mosul Dam, (b) Beaji, and (c) Baghdad. 


\section{CE-QUAL-W2 Model}

We next used the 2-D numerical model CE-QUAL-W2 (W2) to model $T_{w}$ in the Tigris River. W2 is a two-dimensional (longitudinal and vertical) water quality model developed by the U.S. Army Corps of Engineers and Portland State University [35]. W2 simulates river/reservoir water levels, vertical and horizontal velocities, water temperature, and user-defined water quality constituents which include nutrients, algae, dissolved oxygen, and suspended sediment. W2 has been applied to over a thousand reservoirs, lakes, and river systems all over the world [35].

\subsection{W2 Model Inputs}

To run the Tigris River model, initial and boundary conditions of all inflows (mainstem and tributaries), bathymetry, shade file, wind sheltering, and meteorological data were required. The bathymetry of the Tigris River from Mosul Dam (Rkm 0) to Kut Barrage (Rkm 880) were provided from the Iraqi Water Resources Ministry, along with river discharge stage measurements at Mosul Dam, Baeji City, Samarra Barrage, and Baghdad (Figure 1). Satellite estimates of water temperature developed for Mosul Dam and Baeji (see Section 3) were used to define water temperatures for the Upper and the Lower Zab tributaries, respectively, while the water temperature estimated for Baghdad was used to define water temperatures for both the Audaim and Diyala tributaries. The $T_{w}$ upstream boundary condition at Mosul was obtained from daily estimates of $T_{w}$ obtained from statistical models based on satellite data (see Section 3).

\subsection{Meteorological Data of the Tigris River Model}

Meteorological data required to model surface heat transfer includes air and dew point temperature, wind speed and direction, cloud cover and solar radiation. Meteorological data for the year 2009 were provided for three cities with a frequency of every four hours from the General Organization for Meteorology and Seismic Monitoring, housed within the Iraqi Ministry of Transportation. The meteorological stations as shown in Figure 2 were located at the center of Mosul city (about $50 \mathrm{~km}$ south of the upstream model boundary condition at Mosul Dam), at the center of Tikrit city (about $55 \mathrm{~km}$ south of Baeji), and at the international airport in Baghdad (about $18 \mathrm{~km}$ west of Baghdad). Available meteorological data include daily air temperature, dew point temperature, wind speed, and cloud cover at Mosul, Baeji, and Baghdad. Spatially, meteorological data at Mosul were used to cover the study area from Mosul Dam (Rkm 0) to Baeji (Rkm 290), while meteorological data at Baeji and Baghdad were used to cover the study area from Baeji ( $R k m$ 290) to Samarra Barrage ( $R k m$ 390), and from there to Kut Barrage ( $\mathrm{kkm} 880$ ), respectively. Short-wave solar radiation was estimated internally in W2 based on latitude, longitude, time of year, and cloud cover.

\section{W2 Model Development and Calibration}

After developing all boundary condition and forcing function input files, the mainstream of the Tigris River from Mosul Dam (River km 0) to Kut Barrage (River km 880) was simulated for the year 2009.

Flowrates and water levels in the mainstem of the Tigris River were first compared to field data. During flow calibration, additional flow was added or subtracted as distributed tributaries along the mainstem of the Tigris River to account for unknown diversions for agriculture and the return flow caused by additional human activities. The overall percentage error of model predictions of flow rate at Baeji, downstream of Samarra Barrage, and Baghdad was $1.9 \%, 0.8 \%$, and $0.8 \%$, respectively.

After flow calibration, predicted $T_{w}$ was compared to the statistical $T_{w}$ model from satellite imagery. Figure 6 shows W2 model predictions of water temperatures compared with statistical models of $T_{w}$ at both Baeji and Baghdad, respectively. At both stations, W2 model predictions of water temperatures follow the same seasonal pattern as statistical models of $T_{w}$ and lie within the $95 \%$ confidence interval of satellite estimated $T_{w}$. A bias in $\mathrm{W} 2$ model predictions in winter months 
(December, January, and February) was observed and could be due to uncertainty in satellite estimates of water temperatures caused by undetected thin clouds [16] or perhaps seasonal changes in emissivity. Alternatively, we note that the statistical models of $T_{w}$ may be biased towards optimizing summer conditions, given the much larger number of satellite images available during this time period. As a direct result, our numerical model may capture winter conditions less well, due to less certainty in the applied boundary condition. Figure 7 shows diurnal variability in W2 model predictions of water temperature at Baeji and Baghdad during a week in the summer of 2009. Although W2 model predicts diurnal variability of $T_{w}$, all earlier analyses in Section 3 were based on the daily average $T_{w}$. Table 4 lists error statistics in daily average model predictions using meteorological input data with four-hour frequency and with daily average frequency. As expected, the results showed that W2 model predictions of $T_{w}$ using daily average meteorological data produced higher errors compared with W2 model predictions using meteorological input data with a four-hour frequency.
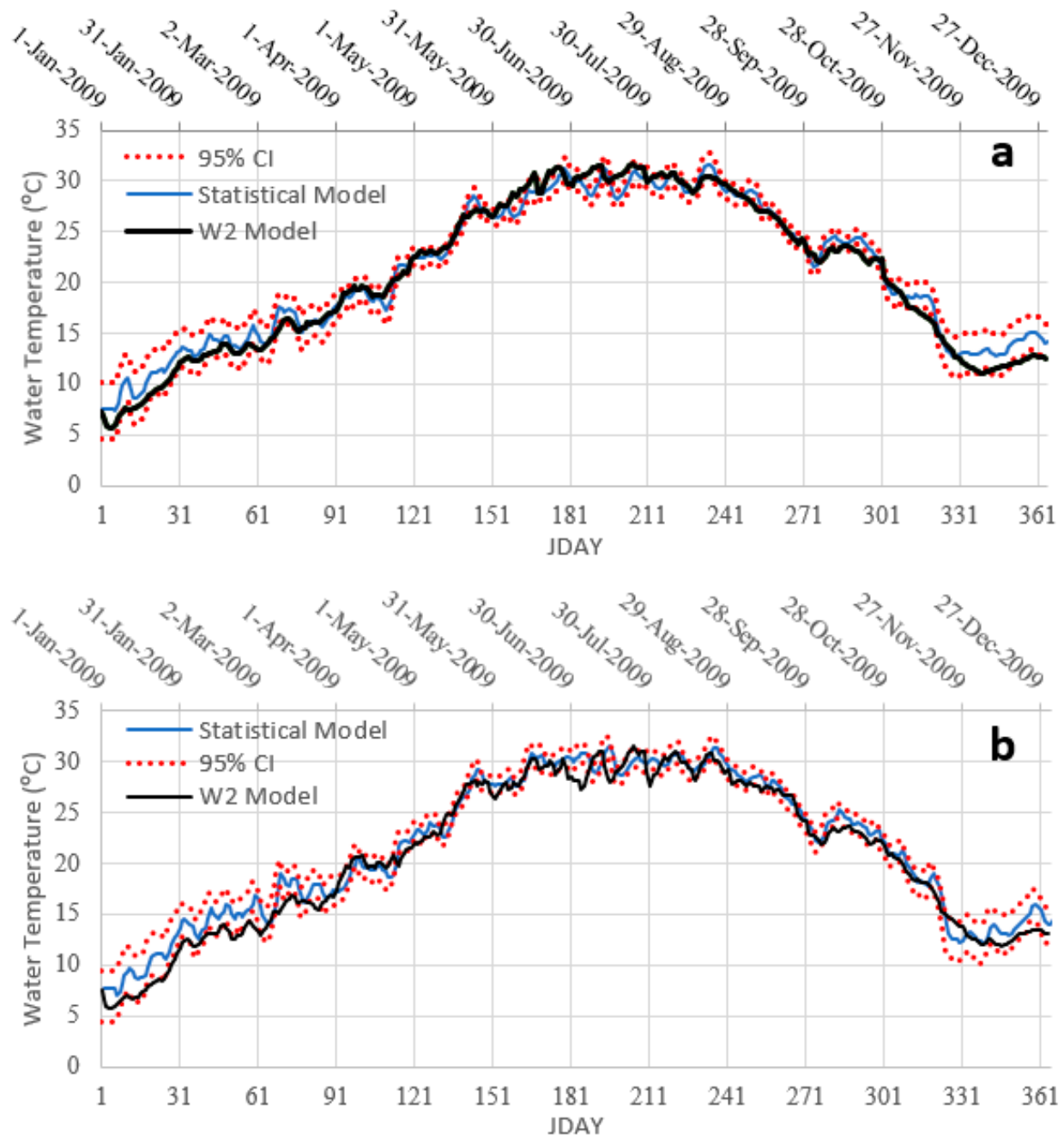

Figure 6. W2 model predictions of $T_{w}$ compared with a statistical model of $T_{w}$ at (a) Baeji and (b) Baghdad.

The model did not generally predict river stratification because the river is shallow and well-mixed vertically. Only in the deeper sections at the Barrages did the model predict limited stratification during the heating period that disappeared during night time cooling.

Compared with the statistical models developed at both Baeji and Baghdad, W2 model predictions were usually biased slightly low with an absolute mean error of $0.93{ }^{\circ} \mathrm{C}$ and $0.97{ }^{\circ} \mathrm{C}$ at Baeji and Baghdad, respectively. To some extent, this may reflect the surface heating that occurs in a thin 
surface film and can bias radiation-based estimates of surface water temperature higher than in situ measurements during the day (see e.g., [25]). The W2 model predictions of $T_{w}$ had a mean error of $0.2{ }^{\circ} \mathrm{C}$ and $0.45^{\circ} \mathrm{C}$ at Baeji and Baghdad, respectively, compared to the statistical model consistent with the [15] observation that Landsat thermal images overestimated in situ stream data on average by $1.2^{\circ} \mathrm{C}$.

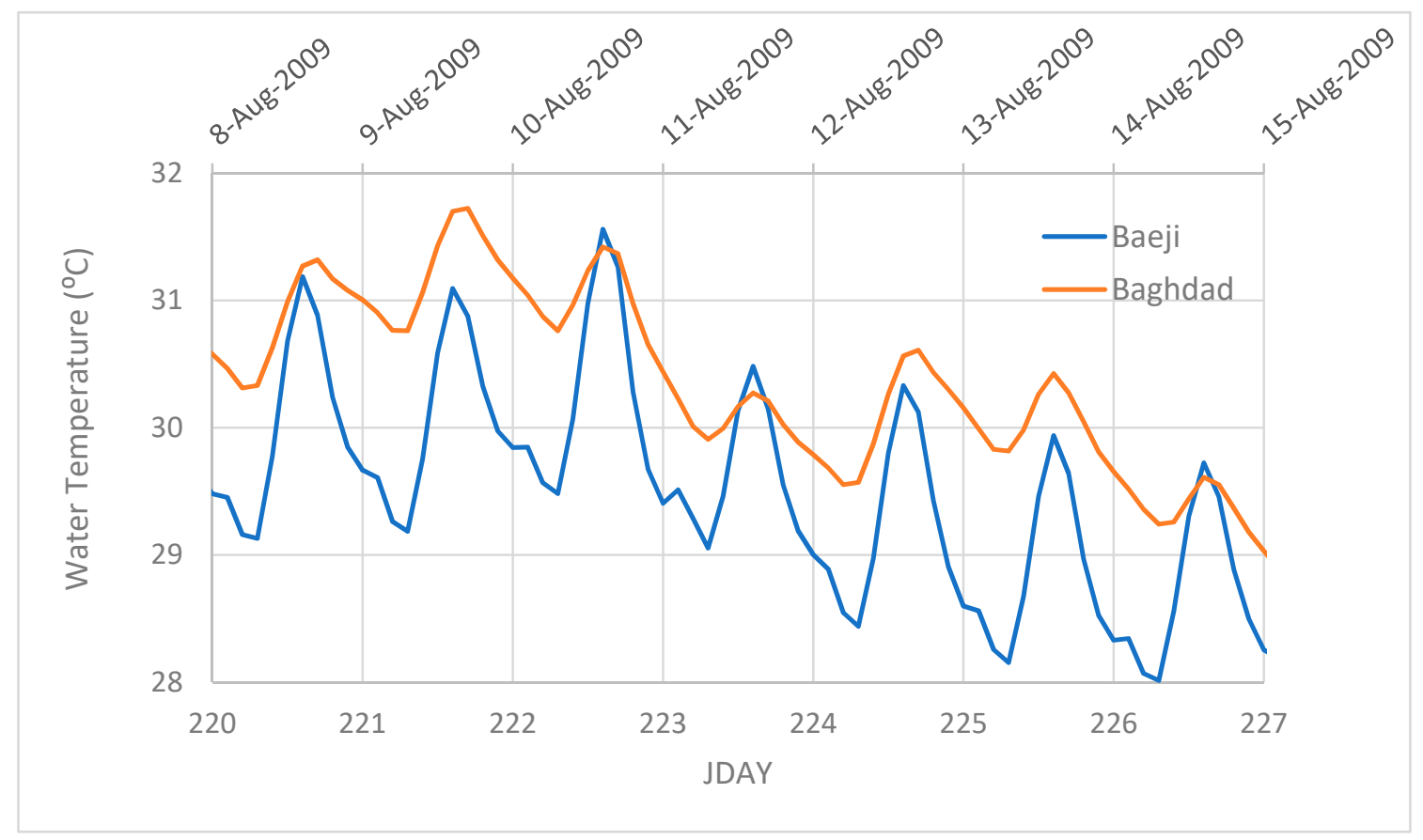

Figure 7. Diurnal variability in model predictions of $T_{w}$ at Baeji and Baghdad.

Table 4. Statistical errors in daily average model predictions of $T_{w}$.

\begin{tabular}{ccccc}
\hline Statistical Error & Four-Hour Meteorological Input Data & \multicolumn{2}{c}{ Daily Average Meteorological Input Data } \\
\hline Error $\left({ }^{\circ} \mathrm{C}\right)$ & Baeji & Baghdad & Baeji & Baghdad \\
$\operatorname{ME}\left({ }^{\circ} \mathrm{C}\right)$ & -0.2 & -0.45 & -0.53 & 0.06 \\
$\mathrm{AME}\left({ }^{\circ} \mathrm{C}\right)$ & 0.93 & 0.97 & 1.52 & 1.04 \\
$\operatorname{RMSE}\left({ }^{\circ} \mathrm{C}\right)$ & 1.17 & 1.2 & 1.52 & 1.25 \\
$\mathrm{~N}$ & 360 & 360 & 360 & 360 \\
\hline
\end{tabular}

\subsection{Scenario Development}

To obtain better insight into the factors which impact water temperature in the Tigris River, multiple scenarios were implemented with the numerical model to simulate the effect of changing management of upstream hydrology and the impact of climate change. These scenarios were then compared with the base W2 model (existing conditions).

The mean annual discharge of the Tigris River at Mosul decreased by 15\% after 1984 [28] as a result of upstream changes in flow management. Therefore, flow boundary conditions at Mosul Dam were increased by $15 \%$ over 2009 levels to study historical river flow conditions and whether flow reduction has impacted downstream water temperatures. In the future, river discharge in the Tigris River is expected to continue to decrease after several dams in Turkey are completed. Therefore, we also studied the effect of a potential further decrease in upstream flow by $15 \%$.

As reported by the Intergovernmental Panel for Climate Change [36], "semi-arid and arid areas are particularly exposed to the impacts of climate change on freshwater (high confidence)." According to [37], mean air temperatures in Iraq during winter and summer in $2020 \mathrm{~s}$ will be $1.7^{\circ} \mathrm{C}$ and $2.1^{\circ} \mathrm{C}$, respectively using GFDL-R15 model, compared to the 1961-1990 period. Therefore, the effects of future climate change on water temperatures in the Tigris River was investigated by increasing air 
temperature by $2{ }^{\circ} \mathrm{C}$. The corresponding dewpoint temperature was also adjusted, assuming a constant relative humidity. Altered air temperature increased the average annual dew point temperatures at Mosul from $7.67{ }^{\circ} \mathrm{C}$ to $9.50{ }^{\circ} \mathrm{C}$, Baeji from $8.20^{\circ} \mathrm{C}$ to $10^{\circ} \mathrm{C}$, and Baghdad from $7.58{ }^{\circ} \mathrm{C}$ to $9.40^{\circ} \mathrm{C}$. We neglected possible changes in precipitation and run-off, since the sensitivity of the system to river flow changes is already captured thru the management scenarios described above. This level of climate change was consistent with [38] estimate of future climate change impacts on temperatures in Iraq.

\subsection{Model Management Scenarios}

Water temperatures in 2009 were simulated to be slightly cooler, in general, under a historical flow regime (Figure 8). Compared with the base W2 model, increasing upstream river flow by $15 \%$ (MS1) produced a temperature difference that varied between -0.18 to $0.06{ }^{\circ} \mathrm{C}$ at Baeji and between 0.18 to $0.13^{\circ} \mathrm{C}$ at Baghdad.
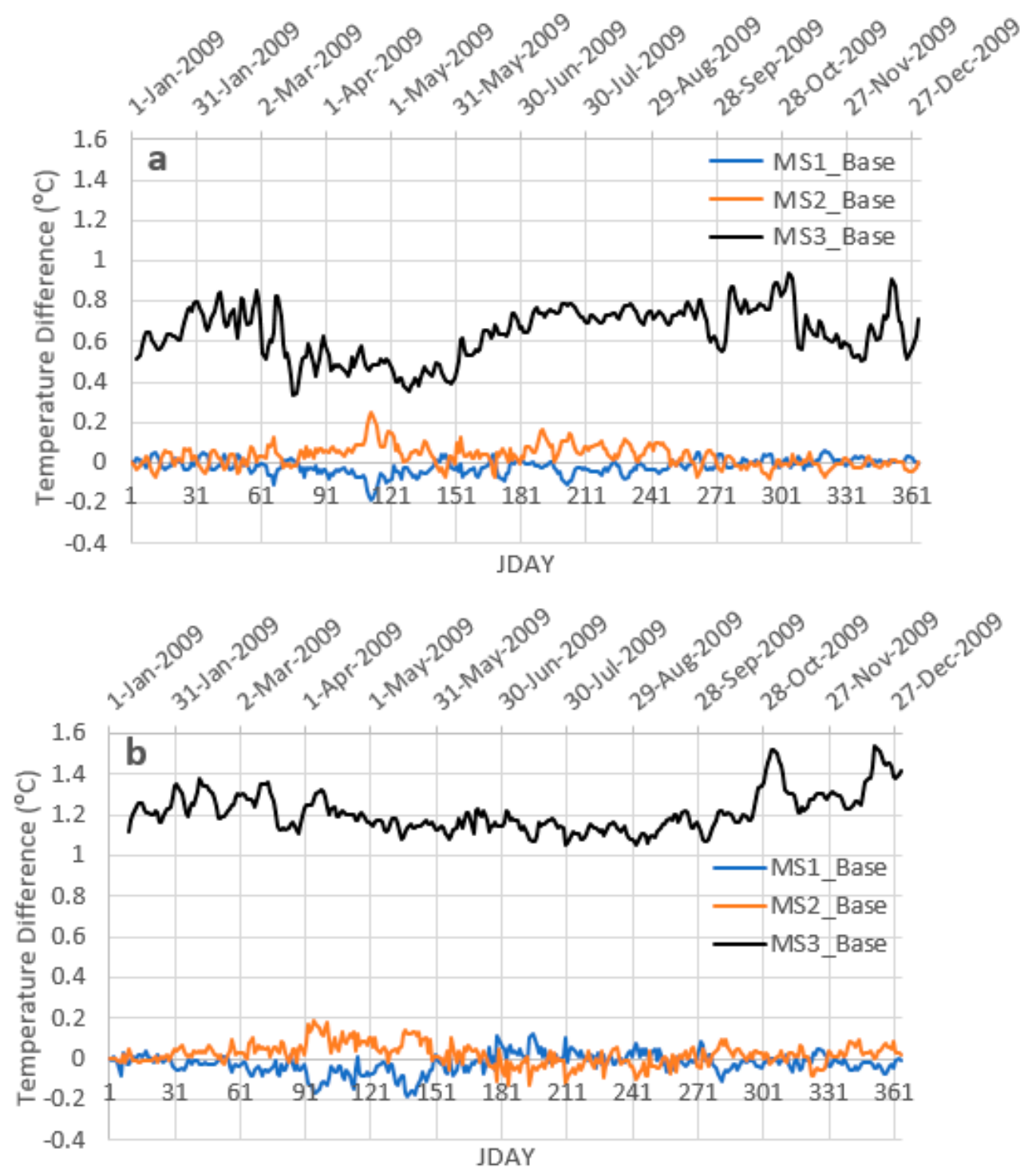

Figure 8. Model differences of water temperatures at (a) Baeji, (b) Baghdad for the base model (existing conditions), MS1: increasing upstream flow, MS2: decreasing upstream flow, and MS3: impacts of climate change.

Compared with the base W2 model, decreasing upstream flow at Mosul Dam by 15\% (MS2) on aggregate slightly increased water temperatures (Figure 8). Results showed the temperature differences 
at Baeji and Baghdad varied between -0.08 to $0.25^{\circ} \mathrm{C}$ and -0.13 to $0.19{ }^{\circ} \mathrm{C}$ respectively, with the largest increases during spring and the smallest during fall. Since flow decreases are most likely to be apparent during the spring freshet in March-May, our results likely underestimated $T_{w}$ changes during that time of year.

W2 model predictions of the longitudinal profile of $T_{w}$ in the Tigris River (Figure 9) shows an impact on $T_{w}$ as a result of changing the upstream flow. The locations of the greatest changes in temperature are related to flow affecting the location of the daily maximums and daily minimums in the river.

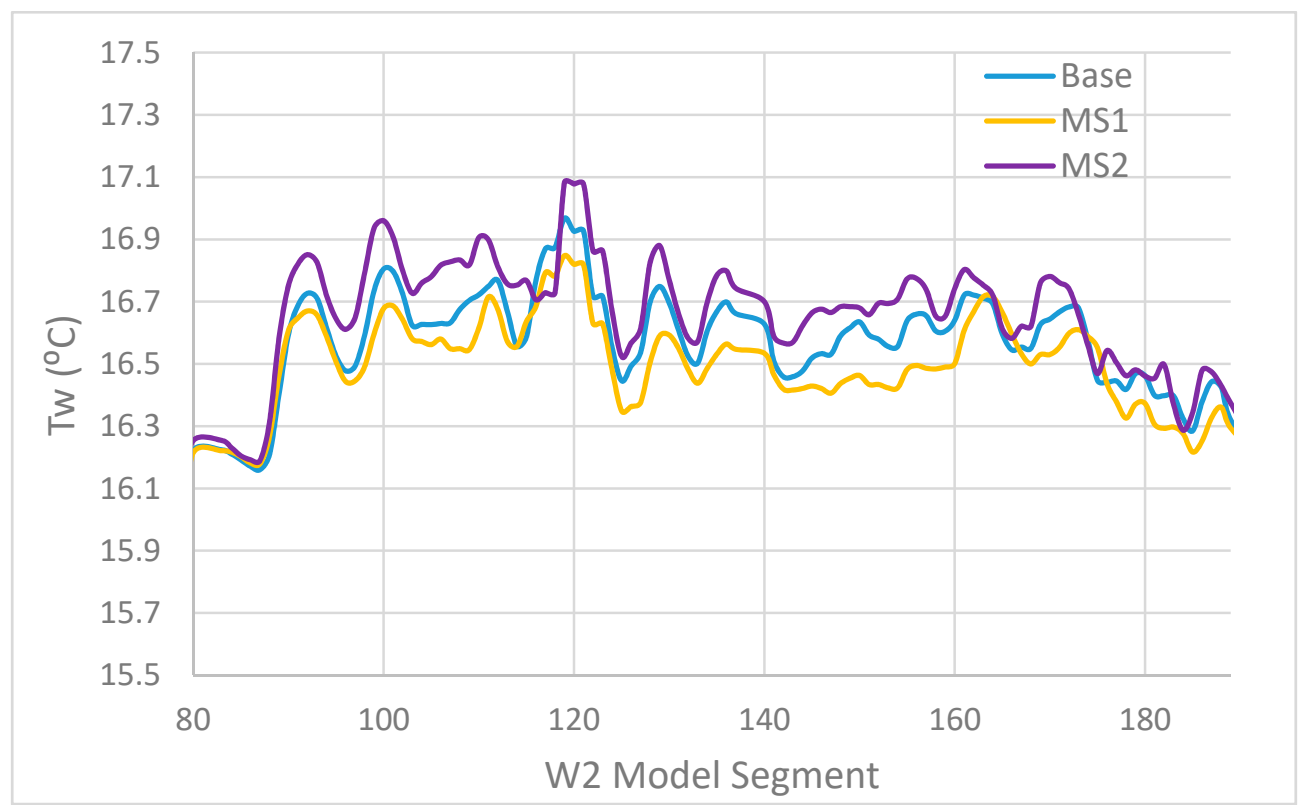

Figure 9. Longitudinal profile of $T_{w}$ in the Tigris River from Baghdad to Kut Barrage at JDAY 72.

W2 model results suggested that future climate change (MS3) will significantly impact water temperatures. For 2009 flow conditions in a warmer climate, simulated $T_{w}$ (Figure 8) increased to $0.94{ }^{\circ} \mathrm{C}$ at Baeji and to $1.54{ }^{\circ} \mathrm{C}$ at Baghdad, with the largest increases occurring during the summer season. While we only modeled the effect of increased air temperature and dew point, the lack of sensitivity to flow rates (Figure 8) suggests that the effect of any altered seasonal precipitation patterns or annual mean precipitation will have only minor effects on water temperature, with the largest effects observed during the spring (see below).

The effects of altered river flow on $T_{w}$ are largest during the spring freshet from April to May with a difference of about $\pm 0.2{ }^{\circ} \mathrm{C}$, due to the larger influence of along-channel advective terms in the energy balance (Figure 8).

Hence, seasonal variation in $T_{w}$ of the Tigris River is highly affected by meteorological forcing data and atmospheric heat flux, including short-wave solar radiation, long-wave atmospheric radiation, back radiation, evaporation, and conduction. Figure 10 shows W2 model predictions of monthly average heat fluxes in the Tigris River at Baeji and Baghdad, in which atmospheric heat flux, a function of air temperature, is the dominant input flux. Also, compared with Baeji, evaporation, and conduction fluxes are higher in Baghdad because of the higher water temperatures. Therefore, dissolved oxygen and other water quality constituents, which depend on hydro-chemical reactions, likely face increasing pressure as the climate warms. 


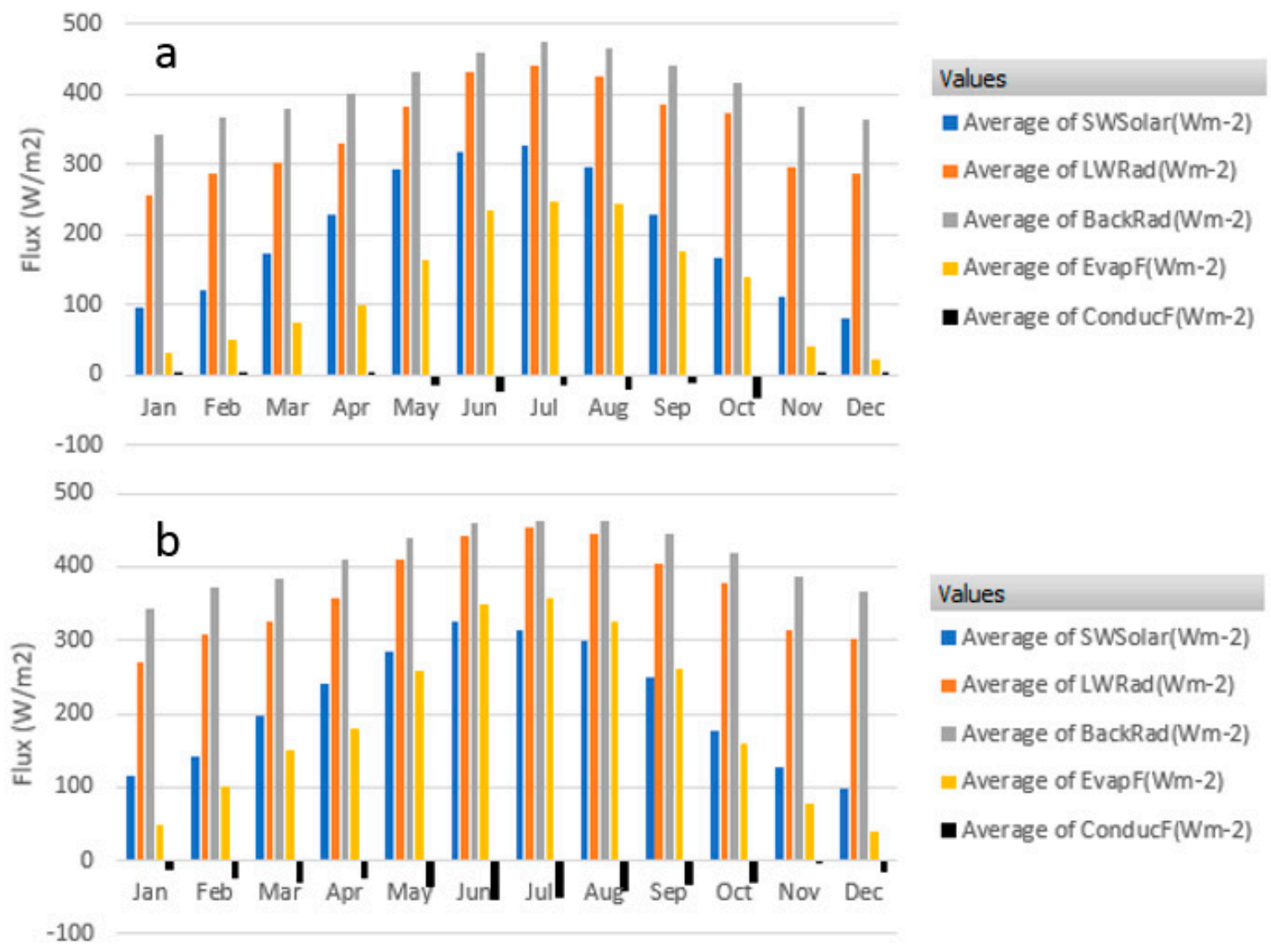

Figure 10. W2 model predictions of monthly average heat fluxes in the Tigris River at (a)Baeji, (b) Baghdad. SWSolar: short-wave solar radiation, LWRad: long-wave atmospheric radiation, BackRad: back radiation, EvapF: evaporation, and ConducF: conduction.

\section{Conclusions}

Water temperatures $\left(T_{w}\right)$ of the Tigris River from Mosul Dam (River km 0) to Kut Barrage (River $\mathrm{km} \mathrm{880)}$ were modeled for the year 2009 using the 2-D hydrodynamic and water quality model CE-QUAL-W2. Satellite data from Landsat 5 TM and Landsat 7 ETM+ sensors were used to estimate $T_{w}$ for upstream boundary conditions and for downstream model calibration. Remote sensing proved to be a feasible method for integrating satellite-based data to estimate $T_{w}$ in the Tigris River. Statistical algorithms for water temperatures at Mosul Dam, Baeji, and Baghdad were developed by correlating satellite data to daily air temperatures. The flowrate of the Tigris River affects temperature by controlling the water depth and the response time. However, flowrate, as an independent variable, proved to be a weak predictor of $T_{w}$. This is confirmed by W2 model sensitivity studies, which showed that changing river flow by $15 \%$ produced only slight changes in $T_{w}$, well under the statistical error of satellite estimates. W2 model predictions of $T_{w}$ at Baeji and Baghdad showed a bias in winter months, possibly due to undiagnosed issues with the underlying satellite data or a bias in the statistical models towards fitting summer conditions. W2 model predictions of $T_{w}$ at Baeji and Baghdad showed less error using meteorological input data with four-hours frequency compared with W2 model predictions using daily average data. Hence, finer resolution meteorological data than daily average is important for temperature modeling of river systems.

Overall, the temporal variation in $T_{w}$ was mainly controlled by the atmospheric heat flux and is thus more sensitive to future changes in the surface energy flux (the climate change scenario MS3) than altered flow conditions caused by either flow management or precipitation changes. A modeled 15\% increase in upstream flow at Mosul Dam showed a maximum decrease of $0.18^{\circ} \mathrm{C}$ in $T_{w}$ at Baeji and Baghdad, respectively, while decreasing upstream flow resulted up to $0.25^{\circ} \mathrm{C}$ and $0.19{ }^{\circ} \mathrm{C}$ maximum 
increase in $T_{w}$ at Baeji and Baghdad, respectively. On the other hand, climate change scenario showed as much as a $0.94{ }^{\circ} \mathrm{C}$ and $1.54{ }^{\circ} \mathrm{C}$ increase in $T_{w}$ at Baeji and Baghdad, respectively, in the summer season. On average, a 2-degree increase in average annual air temperature increased the average annual water temperature from $20.71{ }^{\circ} \mathrm{C}$ to $21.70{ }^{\circ} \mathrm{C}$. The implications of such future water temperature increase to the water quality of the Tigris are not negligible and will be investigated in a future paper.

Author Contributions: M.D.A.-M. conducted data acquisition, processed satellite data, developed the statistical and numerical model, analyzed the data, produced figures, and led the drafting of the paper; S.A.W. reviewed statistical models and model development, and provided significant suggestions on the model results and management scenarios; S.A.T. supported the image processing of satellite data, helped define the statistical model, and provided helpful insights into physical processes and data analysis. All authors helped interpret results and write the paper, and edited, reviewed and approved the final manuscript.

Funding: This research was funded partially by Stefan A. Talke. Funding for Stefan A. Talke was provided by the US National Science Foundation (Career Award 1455350).

Acknowledgments: The authors would like to thank the higher committee for education development in Iraq. Thanks also to the Iraqi Ministry of Water Resources and the Iraqi Ministry of Transportation (the General Organization for Meteorology and Seismic Monitoring) for providing field data used in this research.

Conflicts of Interest: The authors declare no conflict of interest.

\section{References}

1. Rahi, K.A.; Halihan, T. Changes in the Salinity of the Euphrates River System in Iraq. Reg. Environ. Chang. 2010, 10, 27-35. [CrossRef]

2. Wells, S.A.; Berger, C.J. Modeling the Response of Dissolved Oxygen to Phosphorus Loading in Lake Spokane. Lake Reserv. Manag. 2016, 32, 270-279. [CrossRef]

3. Talke, S.A.; De Swart, H.E.; De Jonge, V.N. An Idealized Model and Systematic Process Study of Oxygen Depletion in Highly Turbid Estuaries. Estuaries Coasts 2009, 32, 602-620. [CrossRef]

4. Jurgelenaite, A.; Kriaučiuniene, J.; Šarauskiene, D. Spatial and Temporal Variation in the Water Temperature of Lithuanian Rivers. Baltica 2012, 25, 65-76. [CrossRef]

5. Alcântara, E.H.; Stech, J.L.; Lorenzzetti, J.A.; Bonnet, M.P.; Casamitjana, X.; Assireu, A.T.; de Moraes Novo, E.M.L. Remote Sensing of Water Surface Temperature and Heat Flux over a Tropical Hydroelectric Reservoir. Remote Sens. Environ. 2010, 114, 2651-2665. [CrossRef]

6. Lisi, P.J.; Schindler, D.E.; Bentley, K.T.; Pess, G.R. Geomorphology Association between Geomorphic Attributes of Watersheds, Water Temperature, and Salmon Spawn Timing in Alaskan Streams. Geomorphology 2013, 185, 78-86. [CrossRef]

7. Preston, B.L. Observed Winter Warming of the Chesapeake Bay Estuary (1949-2002): Implications for Ecosystem Management. Environ. Manag. 2004, 34, 125-139. [CrossRef] [PubMed]

8. Raptis, C.E.; van Vliet, M.T.H.; Pfister, S. Global Thermal Pollution of Rivers from Thermoelectric Power Plants. Environ. Res. Lett. 2016, 11, 104011. [CrossRef]

9. Tan, J.; Cherkauer, K.A. Assessing Stream Temperature Variation in the Paci Fi c Northwest Using Airborne Thermal Infrared Remote Sensing. J. Environ. Manag. 2013, 115, 206-216. [CrossRef]

10. Langan, S.J.; Johnston, L.; Donaghy, M.J.; Youngson, A.F.; Hay, D.W. Variation in River Water Temperatures in an Upland Stream over a 30-Year Period. Sci. Total Environ. 2001, 265, 195-207. [CrossRef]

11. Sima, S.; Ahmadalipour, A.; Tajrishy, M. Mapping Surface Temperature in a Hyper-Saline Lake and Investigating the Effect of Temperature Distribution on the Lake Evaporation. Remote Sens. Environ. 2013, 136, 374-385. [CrossRef]

12. Wu, M.; Zhang, W.; Wang, X.; Luo, D. Application of MODIS Satellite Data in Monitoring Water Quality Parameters of Chaohu Lake in China. Environ. Monit. Assess. 2009, 148, 255-264. [CrossRef]

13. Hudson, A.S.; Talke, S.A.; Jay, D.A. Using Satellite Observations to Characterize the Response of Estuarine Turbidity Maxima to External Forcing. Estuaries Coasts 2017, 40, 343-358. [CrossRef]

14. Moran, M.S.; Bryant, R.; Thome, K.; Ni, W.; Nouvellon, Y.; Gonzalez-Dugo, M.P.; Qi, J.; Clarke, T.R. A Refined Empirical Line Approach for Reflectance Factor Retrieval from Landsat-5 TM and Landsat-7 ETM+. Remote Sens. Environ. 2001, 78, 71-82. [CrossRef] 
15. Handcock, R.N.; Gillespie, A.R.; Cherkauer, K.A.; Kay, J.E.; Burges, S.J.; Kampf, S.K. Accuracy and Uncertainty of Thermal-Infrared Remote Sensing of Stream Temperatures at Multiple Spatial Scales. Remote Sens. Environ. 2006, 100, 427-440. [CrossRef]

16. Boer, T. Assessing the Accuracy of Water Temperature Determination and Monitoring of Inland Surface Waters Using Landsat 7 ETM+ Thermal Infrared Images A Case Study on the Rhine River, North Sea Canal and Hollands Diep. Master's Thesis, Delft University of Technology, Delft, The Netherlands, January 2014.

17. Ding, H.; Elmore, A.J. Spatio-Temporal Patterns in Water Surface Temperature from Landsat Time Series Data in the Chesapeake Bay, U.S.A. Remote Sens. Environ. 2015, 168, 335-348. [CrossRef]

18. Khattab, M.F.O.; Merkel, B.J. Application of Landsat 5 and Landsat 7 Images Data for Water Quality Mapping in Mosul Dam Lake, Northern Iraq. Arab. J. Geosci. 2014, 7, 3557-3573. [CrossRef]

19. Lamaro, A.A.; Mariñelarena, A.; Torrusio, S.E.; Sala, S.E. Water Surface Temperature Estimation from Landsat 7 ETM+ Thermal Infrared Data Using the Generalized Single-Channel Method: Case Study of Embalse Del Río Tercero (Córdoba, Argentina). Adv. Space Res. 2013, 51, 492-500. [CrossRef]

20. Liang, S.; Fang, H.; Chen, M. Atmospheric Correction of Landsat ETM+ Land Surface Imagery-Part I. Methods. IEEE Trans. Geosci. Remote Sens. 2001, 39, 2490-2498. [CrossRef]

21. Ling, F.; Foody, G.M.; Du, H.; Ban, X.; Li, X.; Zhang, Y.; Du, Y. Monitoring Thermal Pollution in Rivers Downstream of Dams with Landsat ETM+ Thermal Infrared Images. Remote Sens. 2017, 9, 1175. [CrossRef]

22. Schott, J.R.; Barsi, J.A.; Nordgren, B.L.; Raqueño, N.G.; de Alwis, D. Calibration of Landsat Thermal Data and Application to Water Resource Studies. Remote Sens. Environ. 2001, 78, 108-117. [CrossRef]

23. Simon, R.N.; Tormos, T.; Danis, P. Retrieving Water Surface Temperature from Archive LANDSAT Thermal Infrared Data: Application of the Mono-Channel Atmospheric Correction Algorithm over Two Freshwater Reservoirs. Int. J. Appl. Earth Obs. Geoinf. 2014, 30, 247-250. [CrossRef]

24. Torgersen, C.E.; Faux, R.N.; McIntosh, B.A.; Poage, N.J.; Norton, D.J. Airborne Thermal Remote Sensing for Water Temperature Assessment in Rivers and Streams. Remote Sens. Environ. 2001, 76, 386-398. [CrossRef]

25. Talke, S.A.; Horner-Devine, A.R.; Chickadel, C.C.; Jessup, A.T. Turbulent Kinetic Energy and Coherent Structures in a Tidal River. J. Geophys. Res. Ocean. 2013, 118, 6965-6981. [CrossRef]

26. Reinart, A.; Reinhold, M. Mapping Surface Temperature in Large Lakes with MODIS Data. Remote Sens. Environ. 2008, 112, 603-611. [CrossRef]

27. Wawrzyniak, V.; Piégay, H.P.; Poirel, A. Longitudinal and Temporal Thermal Patterns of the French Rhône River Using Landsat ETM + Thermal Infrared Images. Aquat. Sci. 2012, 74, 405-414. [CrossRef]

28. Al-Ansari, N.; Knutsson, S. Toward Prudent Management of Water Resources in Iraq. J. Adv. Sci. Eng. Res. 2011, 1, 53-67.

29. Giardino, C.; Pepe, M.; Brivio, P.A.; Ghezzi, P.; Zilioli, E. Detecting Chlorophyll, Secchi Disk Depth and Surface Temperature in a Sub-Alpine Lake Using Landsat Imagery. Sci. Total Environ. 2001, 268, 19-29. [CrossRef]

30. Suga, Y.; Ogawa, H.; Ohno, K.; Yamada, K. Detection of Surface Temperature from Landsat-7/ETM+. Adv. Space Res. 2003, 32, 2235-2240. [CrossRef]

31. Wukelic, G.E.; Gibbons, D.E.; Martucci, L.M.; Foote, H.P. Radiometric Calibration of Landsat Thematic Mapper Thermal Band. Remote Sens. Environ. 1989, 28, 339-347. [CrossRef]

32. Al Murib, M. Hydrodynamic and Water Quality Modeling of the Tigris River System in Iraq Using CE-QUAL-W2. Ph.D. Dissertation, Portland State University, Portland, OR, USA, March 2018.

33. Adams, E.E.; Wells, S.A. Field measurements on side arms of Lake Anna, Virginia. J. Hydraul. Eng. ASCE 1984, 110, 773-793. [CrossRef]

34. Fullerton, A.H.; Torgersen, C.E.; Lawler, J.J.; Faux, R.N.; Steel, E.A.; Beechie, T.J.; Ebersole, J.L.; Leibowitz, S.G. Rethinking the Longitudinal Stream Temperature Paradigm: Region-Wide Comparison of Thermal Infrared Imagery Reveals Unexpected Complexity of River Temperatures. Hydrol. Process. 2015, 29, 4719-4737. [CrossRef]

35. Cole, T.; Wells, S. CE-QUAL-W2: A Two-Dimensional, Laterally Averaged, Hydrodynamic and Water Quality Model, Version 4.1; October 2017. Available online: https://www.cee.pdx.edu/w2/ (accessed on 27 April 2019).

36. IPCC. Climate Change 2007: Impacts, Adaptation and Vulnerability. Contribution of Working Group II to the Fourth Assessment Report of the IPCC. 2007. Available online: https:/www.ipcc.ch/site/assets/uploads/ 2018/03/ar4_wg2_full_report.pdf (accessed on 27 April 2019). 
37. El-Fadel, M.; Bou-Zaid, E. Climate Change and Water Resources in the Middle East: Vulnerability, Soci-Economic Impacts, and Adaptation. Available online: https://papers.ssrn.com/sol3/papers.cfm?abstract_ $\mathrm{id}=278514$ (accessed on 18 April 2019).

38. Zakaria, S.; Al-ansari, N.; Knutsson, S. Historical and Future Climatic Change Scenarios for Temperature and Rainfall for Iraq. J. Civ. Eng. Archit. 2013, 7, 1574-1594. 